\title{
PENGARUH MOTIVASI TERHADAP KOMITMEN ORGANISASIONAL PADA GURU MADRASAH IBTIDAIYAH ISLAMIYAH KOTA MADIUN
}

\author{
Elit Prambara Yudha \\ Mahasiswa Program Studi S-1 Ekonomi Islam - Fakultas Ekonomi dan Bisnis - Universitas \\ Airlangga \\ Fatin Fadhilah Hasib \\ Departemen Ekonomi Syariah - Fakultas Ekonomi dan Bisnis - Universitas Airlangga \\ Email: fatin.fadhilah@gmail.com
}

\begin{abstract}
This study aimed to investigate the effect of motivation to organizational commitment of teacher. This research uses questionaire as the primary data and the samples are 67 teachers and candidates of MI Islamiyah Madiun.this research uses quantitative approach with multiple linear regression as the analysis method.

Based on the findings, it obtained multiple linear regression equation : $Y=-0,460+$ $0,666 \times 1+0,473 \times 2$. The result reveals that motivation affect positively and significantly to the organizational commitment of teachers in Madrasah Ibtidaiyah Islamiyah Madiun. It is known from the calculated $F$ vakue of 105,532 with a significance level (probability) of 0,000. Value of the variable t test Motivator and Hygiene partial effect on organizational commitment of teacher in Ml Islamiyah Madiun significance level <0,05.

MI Islamiyah should maintenance motivation of teachers, especially to endure the motivator factors and improve the hygiene factors to achieve organizational commitment of teachers in Ml Islamiyah Madiun
\end{abstract}

Keywords: motivation, motivator, hygiene, organizational commitment.

\section{PENDAHULUAN}

\section{A. Latar Belakang}

Pendidikan berperan besar dalam pembangunan negara. Pembangunan merupakan proses yang berkesinambungan yang mencakup seluruh aspek kehidupan masyarakat, termasuk aspek sosial, ekonomi, politik dan kultural, dengan tujuan utama meningkatkan kesejahteraan warga bangsa secara keseluruhan. Pendidikan berperan sebagai: a) memasyarakatkan ideologi dan nilai-nilai sosio kultural bangsa, b) mempersiapkan tenaga kerja untuk memerangi kemiskinan, kebodohan dan mendorong perubahan sosial, dan c) untuk meratakan kesempatan dan pendapatan (John C. Bock, 1992 dalam Zamroni, 2000:2).

Kualitas pendidikan di Indonesia, terutama ditentukan oleh proses belajar mengajar yag berlangsung di ruang-ruang kelas (Zamroni, 2000:74). Salah satu elemen di dalam kelas tersebut adalah tenaga pengajar atau guru. Guru memiliki peran yang penting dalam proses belajar mengajar. Kualitas dan kuantitas tenaga pengajar haruslah diperhatikan guna mencukupi kebutuhan pendidikan. Seperti yang dikatakan oleh Zamroni (2000:55) bahwa dalam usaha peningkatan kualitas pendidikan disadari satu kebenaran fundamental, yakni bahwa kunci keberhasilan mempersiapkan dan 
menciptakan guru-guru yang profesional, yang memiliki kekuatan dan tanggung jawab yang baru untuk merencanakan pendidikan di Indonesia. Mereka dituntut untuk bekerja secara profesional dan berkomitmen terhadap lembaga pendidikan untuk mencapai tujuan yang tak lain adalah mencerdaskan anak bangsa.

Upaya untuk menemukan kualitas pendidikan yang bermutu, kemampuan guru, kemauan guru dan kesejahteraan guru harus ditingkatkan (Zamroni, 2000:12). Fenomena yang terjadi saat ini, meskipun peran guru sangat besar dalam dunia pendidikan, namun nyatanya kinerja dan kreativitas guru terbatas. Otonomi mereka terbatas oleh kebijakan sekolah. Matinya kreativitas guru ditengarai menjadi penyebab turunnya semangat dan motivasi guru untuk mengajar dengan metode yang menurut mereka positif sehingga proses belajar mengajar menjadi monoton, kaku dan membosankan. Tidak mengherankan bahwa pekerjaan guru merupakan pekerjaan yang tidak menarik bagi individu-individu yang berbakat dan memiliki otak cemerlang, ditambah lagi gaji kecil dan status sosial di masyarakat rendah (Zamroni, 2000:41).

Bagi umat muslim, bekerja merupakan salah suatu ibadah, bahkan menurut Tasmara (1995, dalam Muafi, 2003) makna bekerja bagi seorang muslim adalah suatu upaya yang sungguhsungguh dengan mengerahkan seluruh aset, fikir dan dzikir untuk mengaktualisasikan sebagai hamba Allah
SWT yang harus menundukkan dunia sebagai bagian dari masyarakat yang terbaik. Sehingga apa yang kita kerjakan haruslah dilandasi rasa ikhlas karena Allah SWT dan tidak menimbulkan kemudharatan bagi orang lain. Sehingga tertanam makna spiritualitas dalam bekerja. Seperti firman Allah SWT dalam Al Quran surat At Taubah ayat 105 :

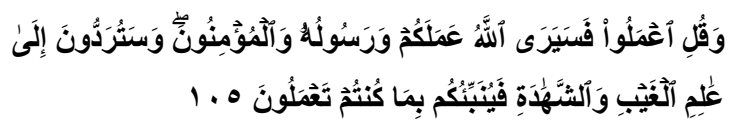

Wa qulimalū fasayarallāhu amalakum warasūluhū wal mu'minūn(a), wasaturaddūna ilā ālimil gaibi wasysyahādati fayunabbi'ukum bimā kuntum ta'malūn.

Artinya : "Dan Katakanlah: Bekerjalah kamu, maka Allah SWT dan Rasulnya serta orang-orang mukmin akan melihat pekerjaanmu itu, dan kamu akan dikembalikan kepada (Allah SWT) yang mengetahui akan yang ghaib dan yang nyata, lau diberitakan-Nya kepada kamu apa yang telah kamu kerjakan." (DEPAG RI, 2010)

Motivasi merupakan salah satu faktor yang mempengaruhi kinerja manusia. Motivasi ini yang juga harus dimiliki oleh guru Madrasah Ibtidaiyah (MI) Islamiyah Kota Madiun. MI memiliki lingkungan kerja religius, artinya dalam setiap visi dan misi serta sistem yang diterapkan sesuai dengan syariat Islam. Lingkungan kerja yang religius tersebut ditengarai merupakan faktor yang membuat guru Ml tersebut mau bertahan dan menunjukkan loyalitasnya. 
Berdasarkan dari uraian di atas dalam kesempatan ini peneliti bermaksud menganalisa apakah motivasi berpengaruh terhadap komiten organisasonal pada Guru Madrasah Ibtidaiyah Islamiyah Kota Madiun. Kajian ini selanjutnya akan diwujudkan dalam bentuk penelitian skripsi dengan judul : "PENGARUH MOTIVASI TERHADAP KOMITMEN ORGANISASIONAL PADA GURU MADRASAH IBTIDAIYAH ISLAMIYAH KOTA MADIUN."

\section{LANDASAN TEORI DAN PENGEMBANGAN HIPOTESIS}

\section{A. Motivasi}

Motivasi adalah suatu dorongan yang menggerakkan seseorang untuk melakukan suatu aktivitas (Djamarah, 1994:50). Motivasi sebagai suatu faktor yang mendorong seseorang untuk melakukan suatu aktivitas tertentu, oleh karena itu motivasi sering kali diartikan pula sebagai faktor pendorong perilaku seseorang (Sutrisno, 2009:115). Winardi (2001:6) memiliki definisi sendiri dari motivasi, yaitu suatu kekuatan potensial yang ada dalam diri seorang manusia, yang dapat dikembangkannya sendiri, atau dikembangkan oleh sejumlah kekuatan luar yang pada intinya berkisar sekitar imbalan moneter dan imbalan non moneter, yang dapat mempengaruhi hasil kinerjanya secara positif atau secara negatif, hal mana tergantung pada situasi dan kondisi yang dihadapi orang yang bersangkutan. Motivasi membuat seseorang akan memiliki semangat yang lebih untuk melakukan suatu pekerjaan.
Motivasi berarti membangkitkan motif, membangkitkan daya gerak, atau menggerakkan seseorang atau diri sendiri untuk berbuat sesuatu dalam rangka mencapai suatu kepuasan atau tujuan (Sobur, 2009:268). Islam memandang motivasi ini sebagai sesuatu yang penting, seperti firman Allah SWT dalam surat Al Baqarah ayat 148 :

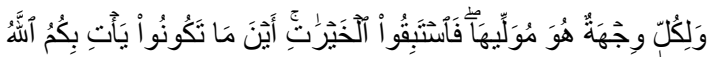

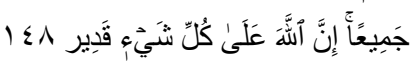

Walikulliw-wijhatun huwa muwallihā, fastabiqul khoirāt(i), ainamā takūnū ya'tibikumullāhu jamīa(n), innallāha 'alā kulli syai'in qodir(un).

Artinya :bagi tiap-tiap umat ada kiblatnya (sendiri) yang ia menghadap kepadanya. Maka berlomba-lombalah (dalam membuat) kebaikan. Dimana saja kamu berada pasti Allah akan mengumpulkan kamu sekalian (pada hari kiamat). Sesungguhnya Allah Maha Kuasa atas segala sesuatu. (DEPAG RI, 2010)

Dari definisi yang telah dijelaskan oleh para peneliti di atas, maka dapat disimpulkan bahwa motivasi adalah dorongan yang muncul dari dalam diri seseorang ataupun pengaruh dari lingkungan luar yang menyebabkan seseorang tersebut memiliki semangat yang tinggi untuk melakukan kegiatankegiatan guna mencapai suatu tujuan tertentu. Motivasi dapat mencakup semua hal yang berasal dari pengaruh situasi luar ataupun dari dalam diri sendiri, sehingga setiap individu memiliki motivasi 
yang berbeda-beda dalam melakukan aktivitasnya sehari-hari.

Umat manusia seharusnya menyadari bahwa salah satu kewajibannya di muka bumi adalah mencari karunia Allah SWT. Karunia Allah SWT atau rezeki bisa diperoleh ketika kita melakukan pencarian, usaha atau bekerja. Rezeki memang telah ditentukan oleh Allah SWT, tetapi kita wajib mencari dan berusaha mendapatkannya. Allah SWT berfirman dalam Surat Al Mulk ayat $15:$

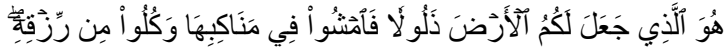

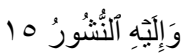

huwalladzī ja 'ala lakumul ardo dzalūlan fāmsyū fì manā kibihā wakulū mi(n)rrizqihī wailaihinnusyūr.

Artinya: Dialah yang menjadikan buni itu mudah bagi kamu, maka berjalanlah di segala penjurunya dan makanlah sebagian dari rezeki-Nya. Dan hanya kepada-Nya-lah kamu (kembali setelah) dibangkitkan. (DEPAG RI, 2010)

Motivasi kerja memiliki hubungan timbal balik antara usaha dengan hasilnya, antara amal dengan pahala. Allah SWT berjanji bahwa Dia tidak akan menyianyiakan setiap pekerjaan manusia barang seberat biji zarrah (atom) pun. Sekecil apapun amal manusia akan mendapat pahala dari Allah SWT. Selain itu nilai-nilai ibadah seharusnya menjadi motivasi yang kuat untuk berbuat kebaikan bagi kehidupan pergaulannya di tengah-tengah masyarakat (Tasmara, 2013:16)

\section{B. Teori Motivasi Klasik}

\section{Hierarki Teori Kebutuhan}

Teori ini dikemukakan oleh Abraham Maslow. Dasar teori ini adalah bahwa manusia merupakan manusia yang keinginannya tak terbatas, alat motivasinya adalah kepuasan yang belum terpenuhi serta kebutuhannya berjenjang (Sunyoto, 2013:2). Menurut Maslow, pada setiap diri manusia itu terdiri dari lima kebutuhan yaitu: kebutuhan secara fisiologis, rasa aman, sosial, penghargaan, dan aktualisasi diri. Kebutuhan tersebut mendorong manusia untuk melakukan sesuatu. seperti terlihat pada gambar berikut :

1. Aktualisasi diri, Kebutuhan untuk menggunakan kemampuan, skill, potensi, kebutuhan untuk berpendapat dengan mengemukakan ide-ide, memberikan penilaian dan kritik terhadap sesuatu.

2. Penghargaan diri, kebutuhan akan harga diri, kebutuhan dihormati dan dihargai orang lain.

3. Kepemilikan sosial, Kepemilikan sosial yaitu kebutuhan merasa memiliki, kebutuhan untuk diterima kelompok, berafiliasi, berinteraksi dan kebutuhan untuk mencintai dan dicintai

4. Rasa aman, kebutuhan rasa aman, kebutuhan perlindungan dari ancaman, bahaya, pertentangan dan lingkungan hidup

5. Kebutuhan fisiologis, kebutuhan makan, minum, perlindungan fisik, seksual sebagai kebutuhan terendah.

Menurut Rivai (2009:864) urutan dan rangkaian kebutuhan seseorang selalu 
mengikuti alur yang dijelaskan oleh teori Maslow. Semakin ke atas kebutuhan seseorang, semakin sedikit jumlah atau kuantitas manusia yang memiliki kriteria kebutuhannya, contohnya kebutuhan kategori self actualization atau kebutuhan kebebasan diri untuk merealisasikan citacita atau harapan individu untuk mengembangkan bakat atau talenta yang dimilikinya.

\section{Teori Herzberg}

Herzberg dalam Daft (2003:98) meyakini bahwa dua dimensi yang benarbenar terpisah yang berkontribusi pada perilaku karyawan di tempat kerja yaitu Faktor Hygiene dan Motivator. Pertama adalah yang disebut faktor Hygiene, yaitu faktor yang melibatkan hadir atau tidaknya ketidakpuasan kerja ljob disatisfiers). Dimensi dalam faktor Hygiene adalah :

a. kondisi kerja,

b. gaji,

c. kebijakan perusahaan

d. hubungan dengan rekan kerja

e. kualitas supervisi

Ketika faktor Hygiene buruk, pekerjaan menjadi tidak memuaskan. Namun, faktor Hygiene yang baik hanya akan menghilangkan ketidakpuasan, faktor tersebut tidak dengan sendirinya menyebabkan orang menjadi termotivasi dalam pekerjaannya (Daft, 2003:98).

Rangkaian faktor kedua yaitu Motivator. Motivator merupakan faktor yang mempengaruhi tingkat kepuasan bekerja berdasarkan pemenuhan kebutuhan tingkat tinggi. Faktor yang berperan sebagai motivator terhadap karyawan yaitu yang mampu memuaskan dan mendorong orang-orang untuk bekerja dengan baik, faktor tersebut terdiri dari:

a. pencapaian (prestasi),

b. penghargaan,

C. tanggungjawab, dan

d. peluang untuk tumbuh

e. pekerjaan itu sendiri

Herzberg dalam Daft (2003:98) meyakini bahwa ketika Motivator tidak ada, pekerja bersikap netral, akan tetapi begitu faktor Motivator tersebut ada, maka pekerja akan termotivasi dan puas. Jadi faktor Hygiene dan Motivator mempresentasikan dua faktor yang berbeda yang mempengaruhi motivasi.

Jadi apa yang dikemukakan oleh Herzberg bahwa kepuasan kerjalah yang dapat mendorong seseorang untuk bekerja. Motivasi yang ada pada seseoarng merupakan kekuatan yang akan mewujudkan suatu perilaku dalam mencapai kepuasan diri (Sunyoto, 2013:1). Faktor Hygiene merupakan faktor pencegah ketidakpuasan, oleh karena itu faktor Hygiene harus tersedia dengan cukup untuk menciptakan suasana yang mungkin seseorang dapat bekerja agar pekerja bekerja dengan baik dan nyaman sehingga dapat meminimalisasi rasa ketidakpuasan. Perusahaan juga harus memahami faktor-faktor apa yang dapat digunakan untuk memotivasi bagi para karyawan.

\section{Mc Clelland's Theory Of Needs}

Teori ini memfokuskan pada tiga hal yaitu : 
a. Need for achievement: kemampuan untuk mencapai hubungan kepada standar perusahaan yang telah ditentukan juga perjuangan karyawan untuk menuju keberhasilan.

b. Need for power: kebutuhan orang untuk berperilaku dalam keadaan wajar dan bijaksana dalam tugasnya masing-masing

c. Need for affiliation: hasrat untuk bersahabat dan mengenal lebih dekat rekan kerja atau para karyawan dalam organisasi.

\section{Teori Motivasi dalam perspektif Islam}

Menurut Ruhul Amin (dalam Khalia dkk, 2012:247-249) ada beberapa cara lain untuk memotivasi orang dalam perspektif Islam, antara lain sebagai berikut :

\section{Hadiah Dan Hukuman}

Penghargaan dan hukuman merupakan faktor yang berperan dalam motivasi. Akan tetapi membutuhkan proses yang panjang untuk menjadikan keduanya sebagi motivator. Dalam Islam, juga ada penghargaan dan hukuman bagi manusia yang keduanya berlaku baik di dunia dan di akhirat. Al Qur'an dan hadis pun juga mengandung berita baik dan peringatan. Keduanya penting untuk membatasi tingkah laku manusia.

Perlu disadari bahwa hukuman itu sendiri sebenarnya bukan sebuah faktor Motivator, melainkan dorongan seseorang menghindari hal yang membuatnya bias dihukum. Pendidikan Islam mengingatkan tentang adanya hukuman. Dalam Islam, hukuman yang diberikan harus sesuai dengan peraturan yang berlaku, dan manjer seharusnya lebih berhati-hati dalam menggunakan kebijakannya. Oleh karena itu, jika karyawan mendapatkan penghargaan atau hukuman dalam pekerjaannya, mereka harus lebih berhatihati lagi dalam bekerja.

\section{Keadilan}

Keadilan merupakan batu pertama dari motivasi. Dalam sebuah organisasi, kasus-kasus seperti larangan bekerja, pemogokan, dan pemberhentian kerja sementaran merupakan suatu hasil dari ketidakadilan. Dengan memebentuk keadilan, organiasasi dapat dengan mudah meningkatkan motivasi. Pekerja harus diyakinkan bahwa pekerjaannya diakui atau paling tidak mereka dihargai ketika bekerja dengan baik. Sebaliknya mereka mungkin akan kehilangan beberapa dorongan untuk menjaga produktivitas dan kualitas. Pekerja harus diperlakukan secara adil dan harus diakui niat baiknya untuk bekerja selama mereka mengemban tugas. Allah SWT menghargai setiap muslim yang adil, seperti dalam firmanNya dalam Al Quran Surat An Nisa' ayat 135 :

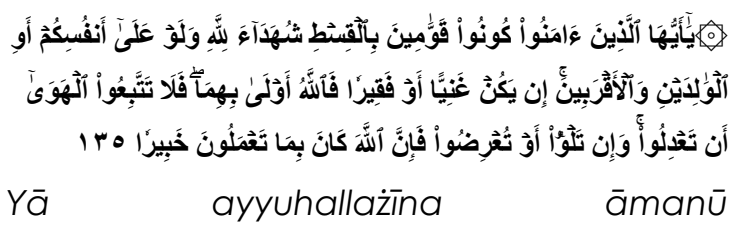
kūnūqowwāminabilqiști syuhadā 'alillāhi wa law 'alā anfusikum awilwā lidaini wal aqribīna in-yakun goniyyan awfaqīron fallāhu awlābihim(a), falātātbi'ul hawā anta: dilū wa intalqū awtu'ri dhū 
fa'innallāha kānabimā ta'malūna khobìron.

Artinya : Wahai orang-orang yang beriman, jadilah kamu orang yang benarbenar penegak keadilan, menjadi saksi karena Allah biarpun terhadap dirimu sendiri atau ibu bapa dan kaum kerabatmu. Jika ia[36]] kaya ataupun miskin, maka Allah lebih tahu kemaslahatannya. Maka janganlah kamu mengikuti hawa nafsu karena ingin menyimpang dari kebenaran. Dan jika kamu memutar balikkan (kata-kata) atau enggan menjadi saksi, maka sesungguhnya Allah adalah Maha Mengetahui segala apa yang kamu kerjakan. (DEPAG RI, 2010)

Akan tetapi hal ini belum cukup bagi manajer untuk bersikap adil, mereka juga harus membuat bawahan yakin bahwa mereka memperhatikannya. Keputusan yang manajer buat seharusnya dijelaskan dengan seksama sehingga pekerja tidak merasakan hal ketidakadilan.

\section{Keterlibatan Peran}

Mengadakan rapat dilakukan sebagai upaya yang terpenting untuk memotivasi karyawan agar mereka terlibat setiap keputusan yang diambil organisasi. Al Quran telah menegaskan bahwa pemimpin muslim wajib untuk berumding dengan orang-orang di organisasi agar dapat memberikan pendapat atau nasihat. Hal ini dijelaskan dalam Al Quran Surat Ali Imran ayat 159 :

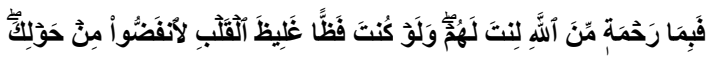

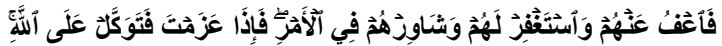

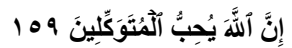

Fabimā rohmatim-minallāhi linatalahum, walaw kunta fazzzō gholl̄zol qolbi lā unfaddū $\min$ houlik(a), fa'fu'anhum wastagfirlahum wa syā wir hum fil amr(i), fa iżā azamta fatawakkal alallāhi innallāha yuhibbul mutawakkilin(a).

Artinya : Maka disebabkan rahmat dari Allah-lah kamu berlaku lemah lembut terhadap mereka. Sekiranya kamu bersikap keras lagi berhati kasar, tentulah mereka menjauhkan diri dari sekelilingmu. Karena itu ma'afkanlah mereka, mohonkanlah ampun bagi mereka, dan bermusyawaratlah dengan mereka dalam urusan itu. Kemudian apabila kamu telah membulatkan tekad, maka bertawakkallah kepada Allah. Sesungguhnya Allah menyukai orangorang yang bertawakkal kepada-Nya. (DEPAG RI, 2010)

\section{Pemberian Gaji}

Dalam Islam, pekerja memiliki suatu hal yang mutlak untuk diterima yaitu gaji atau upah. Hal ini seperti dalam Hadits Nabi Muhammad SAW yang berbunyi : "berikan yang seharusnya diberikan pada pekerja, bayarlah mereka sesuai dengan kemampuan fisik (gaji)."

Hal tersebut jelas bahwa ketika pekerja mendapatkan gaji atau kompensasi, mereka akan mencoba untuk berkontribusi lebih dari kesejahteraan organisasi.

\section{Kebebasan Berpendapat}


Manajer seharusnya memberikan bawahannya untuk menyampaikan pendapat dan secara bebas, bahkan mereka seharusnya melibatkan dalam membuat saran atau kritik yang membangun. Pada masa khalifah, hal tersebut dipertimbangkan sebagai faktor penting dari sebuah kepemimpinan. Dalam pengertian Islam, manajer seharusnya selalu bertindak sebagai pelayan bagi semua orang di organisasi. Pekerja atau bawahan harus dimotivasi untuk menjalankan system ini di organisasi.

\section{Disiplin}

Menegakkan kedisiplinan adalah kunci sukses organisasi. Hal ini mungkin secara nyata dikatakan bahwa sebuah hiasan yang baik dan organisasi yang kaya bisa menjadi semakin buruk jika tidakn menerapkan kedisiplinan. Pekerja akan termotivasi dengan cara menegakkan kedisiplinan dalam kegiatan organisasi. Allah SWT berfirman dalam Al Quran Surat An Nisa' ayat 59 :

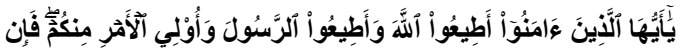

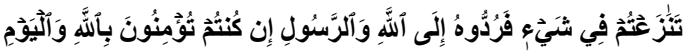

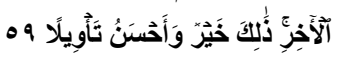

yā ayyuhallażinna āmanū athi'ullāha wa ațī urrasūla wa ülilamri minkum, fain tanāza'tum fì syaīn faruddūhu ilallāhi warrasūli inkuntum tu'minūna billāhi walyaumil akhir(i), żālika khoiru wa ahsanu ta'wilan.

Artinya : Hai orang-orang yang beriman, taatilah Allah dan taatilah Rasul (Nya), dan ulil amri di antara kamu. Kemudian jika kamu berlainan pendapat tentang sesuatu, maka kembalikanlah ia kepada Allah (Al Quran) dan Rasul (sunnahnya), jika kamu benar-benar beriman kepada Allah dan hari kemudian. Yang demikian itu lebih utama (bagimu) dan lebih baik akibatnya. (DEPAG RI, 2010)

\section{Pemeliharaan Kejujuran}

Ini adalah faktor yang penting untuk menciptakan motivasi di organisasi. Baik manajer ataupun pekerja seharusnya selalu bertanggung jawab untuk memelihara kejujuran di organisasi sebagai suatu yang abadi. Pekerja harus dimotivasi dengan cara memberikan suasana yang jujur dan sikap tulus ikhlas dari manajer. Dan pekerja seharusnya melaksanakan tugasnya dengan jujur dan ikhlas. Pekerja yang jujur dalam melayani Allah SWT dan manajernya adalah suatu kesalehan yang tinggi.

\section{Komitmen Organisasional}

Mowday (dalam Sopiah, 2008:155) menyebut komitmen kerja sebagai istilah lain dari komitmen organisasional dan komitmen organisasional merupakan dimensi perilaku yang dapat digunakan untuk menilai kecenderungan karyawan untuk bertahan sebagai anggota organisasi.

Komitmen organisasional menunjukkan sejauh mana seseorang memihak sebuah orhganisasi serta tujuantujuannya dan keinginan untuk mempertahankan keanggotaan dalam organisasi tersebut (Sunyoto, 2013:53). Menurut Goleman (Tasmara, 2002:85) orang yang berkomitmen adalah para warga perusahaan teladan yang bersedia 
menempuh perjalanan lebih panjang. Lebih lanjut, Goleman mengidentifikasikan ciri orang yang berkomitmen antara lain sebagai berikut :

a. sikap rela berkorban demi pemenuhan sasaran perusahaan yang lebih penting.

b. merasakan dorongan semangat dalam misi yang besar.

c. menggunakan nilai-nilai kelompok dalam pengambilan keputusan dan penjabaran pilihan-pilihan.

Robbins (2008:100) menjelaskan bahwa komitmen organisasional adalah tingkat sampai mana seorang karyawan memihak sebiah organisasi serta tujuan tujuan dan keinginannya untuk mmpertahankan keanggotaan dalam organissi tersebut. Menurut Randall dalam Sunyoto (2013:53), komitmen terhadap organisasi terdiri dari tiga komponen utama yaitu : (1) kepercayaan seseorang yang kuat dan menerima tujuan organisasi (2) kesediaan seseorang mengupayakan sekuat tenaga untuk menjadi bagian dari organisasi (3) keinginan seseorang untuk memelihara keanggotaannya.

Berdasarkan teori komitmen di atas, dapat disimpulkan bahwa dalam komitmen tergantung sebuah tekad, keyakinan, yang melahirkan bentuk vitalitas yang penuh gairah, selain itu komitmen merupakan sebuah tindakan keberanian (Tasmara, 2002:86).

\section{E. Komitmen Organisasional dalam Perspektif Islam}

Komitmen adalah suatu perjanjian yang menuntut untuk ditunaikan dan bersifat mengikat. Dalam Islam terdapat istilah komitmen kerja Islami. Komitmen kerja Islami adalah kesediaan dan kerelaan bekerja dengan menepati segala ketentuan kerja dalam ajaran agama Islam (Amin, 2010).

Komitmen sangat penting untuk dimiliki oleh setiap muslim dalam melakukan suatu yang baik. Komitmen dapat diartikan sebagai pengabdian, pengabdian yang baik adalah mengabdi kepada Allah SWT. Tasmara (2002:4) juga berpendapat bahwa menjadi seorang muslim haruslah terlebih dahulu menampilkan dirinya sebagai manusia yang amanah, manusia yang menunjukkan sikap pengabdian karena mereka sadar bahwa kehadiran dirinya di muka bumi tidak lain hanya untuk mengabdi. Seperti dalam firman Allah SWT dalam surat Adz Dzariyaat ayat 56 :

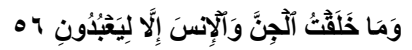

Wa mā kholaqtūjinna wal 'insa illa liya 'budūn.

Artinya : Dan aku tidak menciptakan jin dan manusia melainkan supaya mereka mengabdi kepada-Ku. (DEPAG RI, 2010)

Luth (2001:22) menjelaskan tentang syarat yang harus dimiliki untuk mewujudkan komitmen dalam bekerja agar bisa menjadi suatu amal shaleh, diantaranya sebagai berikut:

a) Ikhlas, yaitu menyatunya badan, pikiran dan hati dalam tugas atau 
aktivitas serasa menyucikan niat karena Allah SWT semata. Bukan untuk prestise atan mencari keuntungan. Bekerja adalah ibadah karena Allah SWT, maka ikhlas harus terpatri di dalam kerja tersebut.

b) Cinta, yaitu adanya rasa rindu untuk mendapat ketenangan atau kebahagiaan bila bertemu dengan yang didamba. Mencintai pekerjaan adalah suatu keharusan, karena di dalamnya kita dapat memperoleh nilai tambah secara materi dan spiritual berupa pengalaman untuk memenuhi hajat hidup kita.

c) Istiqamah, yaitu tetap tekun dengan berpihak pada yang benar. Karena bekerja adalah ibadah maka kita harus istiqamah, tidak boleh menghalalkan segala cara untuk memperoleh penghasilan. Kita harus istiqamah dalam arti tetap berpihak pada yang benar sesuai dengan apa yang diperintahkan agama.

d) Sedia berkorban, diketahui bahwa bekerja sebagai ibadah juga menurut pengorbanan. Pengorbanan dalam hal waktu, tenaga, pikiran, harta benda dan perasaan. Ibadah adalah kerelaan berkorban dan keikhlasan menerima segala cobaan juga sebagai ibadah.

\section{F. Hipotesis} sementara tentang perilaku, fenomena, atau keadaan tertentu yang telah terjadi atau akan terjadi (Kuncoro, 2009:59) Berdasarkan latar belakang, rumusan masalah, tujuan penelitian dan landasan teori, maka hipotesis yang diajukan dalam penelitian ini adalah sebagai berikut :

a. Motivasi berpengaruh secara parsial dan simultan terhadap komitmen organisasional Guru MI Islamiyah Madiun.

b. Faktor Motivator berpengaruh paling dominan terhadap Komitmen Organisasional pada Guru MI Islamiyah Madiun.

\section{METODOLOGI PENELITIAN}

Pendekatan penelitian yang digunakan dalam penelitian ini adalah pendekatan kuantitatif, yang bertujuan untuk menguji hipotesis, dengan data yang terukur dan menghasilkan kesimpulan yang dapat digeneralisir. Langkah awal dalam melakukan penelitian kuantitatif dimulai dengan menentukan hipotesis, langkah selanjutnya membuat model analisis, indentifikasi variabel, definisi operasional, pengumpulan data (primer maupun sekunder) berdasarkan populasi dan sampel penelitian, serta melakukan analisis. Variabel yang digunakan dalam penelitian ini dapat diidentifikasikan menjadi 2 (dua) variabel, yaitu:

a. Variabel independen, (X1) yaitu Motivator dan (X2) yaitu Hygiene.

b. Variabel dependen (Y), yaitu komitmen organisasional. 


\section{A. Definisi Operasional Variabel}

\section{Motivator (X1)}

Faktor Motivator adalah faktor yang mempengaruhi tingkat kepuasan bekerja berdasarkan pemenuhan kebutuhan tingkat tinggi (job satisfiers). Faktor ini bersifat intrinsik dan bersumber dari dalam diri seseorang serta berhubungan dengan penghargaan terhadap pribadi yang secara langsung berkaitan dengan pekerjaan.

Indikator faktor Motivator ini adalah :

a. Pencapaian (prestasi)

Menurut Kamus Besar Bahasa Indonesia (1998), kata prestasi berarti hasil yang telah dicapai dari apa yang telah dilakukan. Sedangkan prestasi kerja adalah hasil kerja yang telah dicapai seorang karyawan dalam melaksanakan tugas yang diberikan kepadanya. Hasil kerja atau prestasi tersebut untuk menambah peluang untuk kenaikan pangkat atau mendapat penghargaan dari atasan.

b. Pengakuan dan penghargaan Pengakuan dan penghargaan dari orang lain dapat dijadikan sebagai motivator. Menurut Sutrisno (2009:125) pengakuan dan penghargaan bagi seorang karyawan meliputi hal-hal :

1. pengakuan dan penghargaan dari atasan dan rekan kerja

2. pimpinan yang adil dan bijaksana

3. perusahaan tempat bekerja dihargai oleh masyarakat

c. Tanggung jawab Menurut Kamus Besar Bahasa Indonesia tanggung jawab adalah keadaan wajib untuk menanggung segala sesuatunya. Dengan menduduki jabatan, seseorang akan merasa akan dipercaya, diberi tanggung jawab, dan wewenang yang besar untuk melakuan kegiatankegiatan. Hal tersebut akan berdampak terhadap kedisiplinan karyawan dalam bekerja.

d. Peluang untuk tumbuh Kebutuhan untuk menjadi produktif dan kreatif, misalnya diberdayakan di dalam potensi dan berkembang secara terus menerus. Diadakannya pelatihan dalam hal pengajaran murid merupakan cara yang cukup efektif untuk meningkatkan kemampuan guru dalam mengajar.

e. Pekerjaan itu sendiri.

Profesi guru merupakan pekerjaan yang sangat umum di kalangan masyarakat indonesia. Suatu pekerjaan menyediakan kesempatan seseorang untuk belajar, memperoleh tanggung jawab dalam suatu tugas tertentu dan tantangan pekerjaan yang menarik.

\section{Hygiene (X2)}

Faktor Hygiene adalah faktor yang melibatkan hadir atau tidaknya ketidakpuasan kerja (job disatisfiers). Faktor ini bersifat ekstrinsik dan bersumber dari luar diri seseorang. Faktor Hygiene merupakan faktor yang harus diberikan oleh pimpinan demi kesehatan, kepuasan dan kesejahteraan bawahannya. Indikator Faktor Hygiene adalah :

a. Gaji 
Menurut Kamus Besar Bahasa Indonesia gaji adalah balas jasa yang diterima pekerja dalam bentuk uang berdasarkan waktu tertentu. Gaji merupakan sumber penghasilan utama bagi para karyawan untuk menghidupi diri sendiri beserta keluarganya. Menurut Sutrisno (2009:126) gaji yang memadai merupakan alat motivasi yang paling ampun bagi perusahaan untuk mendorong para karyawan bekerja dengan baik.

b. Kondisi kerja

Berdasarkan pendapat yang dikemukakan oleh Sutrisno (2009:126), lingkungan pekerjaan adalah keseluruhan sarana dan prasarana kerja yang ada di sekitar karyawan yang sedang melakukan pekerjaaan yang dapat mempengaruhi pelaksanaan pekerjaan. Lingkungan kerja ini meliputi tempat bekerja, fasilitas dan alat bantu pekerjaan, kebersihan, pencahayaan, ketenangan, termasuk juga berhubungan kerja antara orangorang yang ada di tempat tersebut.

c. Kebijakan perusahaan

Menurut Sutrisno (2009:129) menyatakan bahwa bagi organisasi besar, biasanya sudah ditetapkan sistem dan prosedur kerja yang harus dipatuhi oleh seluruh karyawan. Sistem dan prosedur kerja ini dapat kita sebut dengan peraturan yang berlaku dan bersifat mengatur dan melindungi para karyawan. Pemberian sanksi atau hukuman haruslah dilakukan secara bijaksana.

d. Hubungan dengan rekan kerja
Rekan kerja secara teknis cakap dan secara sosial mendukung tugas rekanrekan kerja lainnya.

e. Kualitas supervisi

Menurut Kamus Besar Bahasa Indonesia supervisi adalah pengawasan utama. Dalam penelitian ini, pengawasan tersebut dilakukan oleh Kepala Sekolah sebagai pengawas tertinggi di sekolah. Kemampuan kepala sekolah untuk bisa adil dalam memberikan bantuan teknis kepada para guru dan dukungan terhadap pekerjaan yang menjadi tanggung jawab para guru.

\section{Komitmen Organisasional $(Y)$}

Mowday (dalam Sopiah, 2008:155) menyebut komitmen kerja sebagai istilah lain dari komitmen organisasional dan komitmen organisasional merupakan dimensi perilaku yang dapat digunakan untuk menilai kecenderungan karyawan untuk bertahan sebagai anggota organisasi. Komitmen kerja Islami adalah kesediaan dan kerelaan bekerja dengan menepati segala ketentuan kerja dalam ajaran agama Islam (Amin, 2010).

Berdasarkan Randall dalam Sunyoto (2013:53) dan Luth (2001:22) yang diimplementasikan pada MI Islamiyah Madiun, indikator atas variabel komitmen organisasional perspektif Islam adalah sebagai berikut :

1. bekerja dengan ikhlas sebagai niat ibadah kepada allah swt

2. merasa nilai-nilai yang ada di mi islamiyah adalah benar sesuai dengan apa yang diperintahkan agama 
3. mencintai pekerjaan yang dilakukan dan juga organisasi tempat bekerja yaitu mi islamiyah

4. bersedia mengupayakan sekuat tenaga untuk menjadi bagian dari mi islamiyah

5. bekerja dengan sungguhsungguh untuk memelihara keanggotaan di mi islamiyah

6. menerima tujuan mi islamiyah dan berusaha untuk mewujudkannya

7. bersedia mengorbankan waktu, tenaga, pikiran, harta benda, dan perasaan untuk mi islamiyah madiun

\section{B. Prosedur Pengumpulan Data}

Prosedur pengumpulan data dalam penelitian ini dilakukan dengan cara:

1. Studi kepustakaan, yakni dengan mempelajari dan mengumpulkan teoriteori dari berbagai literatur dan buku bacaan lain yang berkaitan dengan permasalahan yang sedang dibahas dalam penelitian ini.

2. Penelitian pendahuluan, yaitu dengan mengadakan peninjauan dan penelitian secara umum, untuk mendapatkan informasi dan mengetahui permasalahan yang akan diangkat dalam penelitian ini.

3. Penyebaran kuesioner, yaitu dilakukan dengan cara menyebarkan kuesioner kepada karyawan Waroeng Steak \& Shake dengan mengajukan daftar pertanyaan secara singkat mengenai topik pembahasan penelitian ini, kemudian dilanjutkan dengan mengolah dan menganalisa data tersebut dengan metode statistik.

\section{Teknik Analisa Data}

Model analisis yang digunakan dalam penelitian ini berbentuk regresi linier berganda. Model analisis ini digunakan untuk mengetahui pengaruh variabel independen terhadap variabel dependen.

\section{DESKRIPSI HASIL DAN PEMBAHASAN}

\section{A. Hasil Analisis Regresi Linear Berganda}

Tabel 1.

Hasil Uji Regresi Linear Sederhana

\begin{tabular}{|c|c|c|c|c|}
\hline \multirow{2}{*}{ Variabel } & \multicolumn{2}{|c|}{ Koefisien } & \multirow[b]{2}{*}{ thit. } & \multirow[b]{2}{*}{ Sign. } \\
\hline & $\begin{array}{c}\text { Koef. } \\
\text { Reg. }\end{array}$ & Beta & & \\
\hline Konstanta & $\begin{array}{c}- \\
0,460\end{array}$ & & $\begin{array}{c}- \\
1,642\end{array}$ & 0,106 \\
\hline Motivator & 0,666 & 0,507 & 6.384 & 0,000 \\
\hline Hygiene & 0,473 & 0,457 & 5.746 & 0,000 \\
\hline \multicolumn{3}{|c|}{ Multiple $R=0,876$} & \multirow[t]{2}{*}{ F Hitung } & $=$ \\
\hline 105,532 & $N=67$ & & & \\
\hline $\begin{array}{l}\text { R Square }= \\
0,000\end{array}$ & & & Sign & $=$ \\
\hline
\end{tabular}

Nilai dari koefisien determinasi dari hasil regresi pada penelitian ini adalah 0,767 yang berarti bahwa sebesar 76,7 \% komitmen organisasional (variabel tergantung) mampu dijelaskan oleh variabel bebas, sedangkan sisanya sebesar 23,3\% dijelaskan oleh variabel lain yang tidak dimasukkan dalam model (faktor galat).

Berdasarkan hasil analisis regresi linear sederhana yang dilakukan pada 
penelitian ini diperoleh nilai koefisien korelasi berganda atau Multiple (R) sebesar 0,876. Nilai $R$ sebesar 0,876 menunjukkan adanya hubungan yang cukup tinggi antara variabel bebas $(X)$ dengan variabel tergantung $(\mathrm{Y})$.

\section{B. Uji Hipotesis}

1. uji $\mathbf{F}$

Nilai F hasil regresi adalah sebesar 105,532, dengan nilai probabilitas kesalahan (Sig) sebesar 0,000 . Nilai signifikansi ini lebih kecil dari 0,05 sehingga ada pengaruh secara simultan variabel bebas Motivator dan Hygiene terhadap variabel terikat (Y) Komitmen Organisasional. Dengan demikian hipotesis pertama yang menyatakan "Terdapat pengaruh secara simultan yang signifikan Motivator dan Hygiene terhadap Komitmen Organisasional diterima kebenarannya.

\section{Uji $t$}

Pengujian hipotesis koefisien regresi secara parsial (uji t) ditunjukkan untuk mengetahui pengaruh variabel bebas secara parsial terhadap variabel tergantung dalam satu model. Hasil uji parsial dipaparkan selengkapnya pada Tabel berikut:

Tabel 2.

Hasil Uji Regresi Secara Parsial (Uji †)

\begin{tabular}{|c|c|c|}
\hline Variabel & $\dagger$ & $\begin{array}{c}\text { Tingkat } \\
\text { signifikansi }\end{array}$ \\
\hline Motivator & 6,384 & 0.000 \\
\hline Hygiene & 5,746 & 0.000 \\
\hline
\end{tabular}

Berdasarkan tabel tersebut dapat dijelaskan sebagai berikut:

1. Variabel Motivator $\left(X_{1}\right)$
Formulasi hipotesis statistik $\mathrm{Ho}=\mathrm{b}_{1}$

$=0 ; \mathrm{Ha} \neq \mathrm{b}_{1} \neq 0$

Nilai uji $\dagger$ untuk variabel Motivator $\left(X_{1}\right)$ adalah sebesar 6,384 dengan tingkat signifikasi 0.000 . Nilai signifikasi ini lebih lebih kecil dari 0,05 , sehingga dapat dinyatakan ada pengaruh secara parsial variabel Motivator $\left(X_{1}\right)$ terhadap Komitmen Organisasional.

2. Variabel Hygiene

Formulasi hipotesis statistik $\mathrm{Ho}=\mathrm{b}_{2}$ $=0 ; \mathrm{Ha} \neq \mathrm{b}_{2} \neq 0$

Nilai uji † untuk variabel Hygiene $\left(X_{2}\right)$ adalah sebesar 5,746 dengan tingkat signifikasi 0.000 . Nilai signifikasi ini lebih lebih kecil dari 0,05 , sehingga dapat dinyatakan ada pengaruh secara parsial variabel Hygiene $\left(X_{2}\right)$ terhadap Komitmen Organisasional.

\section{Variabel Berpengaruh Dominan}

Tabel 3.

Perhitungan Nilai Beta

\begin{tabular}{|c|c|}
\hline Variabel & Beta \\
\hline Motivator & 0.507 \\
\hline Hygiene & 0,457 \\
\hline \multicolumn{2}{|c|}{ Berdasarkan hasil } \\
\hline
\end{tabular}

menunjukkan nilai beta untuk variabel Motivator merupakan variabel yang berpengaruh dominan dengan nilai beta terbesar yaitu 0.507 Ini berarti dibandingkan dengan variabel Hygiene maka variabel Motivator merupakan yang berpengaruh dominan terhadap Komitmen Organisasional. 


\section{Pembahasan}

Penelitian mengenai pengaruh motivasi yang terdiri faktor Motivator dan Hygiene terhadap Komitmen Organisasional sudah dilaksanakan di MI Islamiyah Madiun. Pihak MI Islamiyah Madiun sudah memberikan ijin kepada peneliti untuk melakukan penelitian terhadap guru. Untuk melengkapi pembahasan peneliti juga melakukan survey, wawancara kepada beberapa guru dan kepala sekolah dan juga mengamati suasana belajar di sekolah tersebut. Wawancara dan pengamatan tersebut diharapkan dapat membantu peneliti menjelaskan hubungan antra variabel yang dapat menambah pembahasandan menjelaskan fenomena yang terjadi.

Hasil kuesioner menunjukkan bahwa ketiga variabel, yaitu Motivator, Hygiene dan Komitmen Organisasional rata-rata memiliki respon yang sangat tinggi. Hal tersebut menunjukkan bahwa faktor Motivator yang merupakan faktor yang bersifat intrinsik yaitu yang bersumber dalam diri sendiri sudah dimiliki oleh para guru MI Islamiyah Madiun. Faktor Hygiene juga menunjukkan respon yang sangat tinggi. Hal tersebut menunjukkan bahwa faktor Hygiene dirasa sudah memberikan kepuasan guru dalam bekerja. Faktor Hygiene adalah faktor yang bersifat konkrit yang berasal dari luar diri seseorang (ekstrinsik). Variabel yang ketiga yaitu Komitmen Organisasional yang diukur dengan 7 item pertanyaan juga menunjukkan respon yang sangat tinggi dari para Guru Ml Islamiyah Madiun. Variabel Komitmen Organisasional harus dipertahankan oleh manajemen atau perserikatan MI Islamiyah guna membuat para guru bersedia bertahan di organisasi dan melakukan pekerjaan dengan baik.

Berdasarkan hasil analisis koefisien korelasi, menunjukkan untuk variabel Motivator (X1) dan Hygiene (X2) secara simultan mempunyai hubungan yang kuat dan positif terhadap Komitmen Organisasional guru (Y), atau dengan kata lain semakin positif variabel Motivator (X1) dan Hygiene (X2) maka semakin positif pula Komitmen Organisasional (Y) guru MI Islamiyah madiun.

Perhitungan nilai $F$ hitung menghasilkan nilai signifikansi sebesar 0,000 . Nilai probabilitas ini kemudian dibandingkan dengan level of significant sebesar0,05. Karena nilai probabilitas ini lebih kecil daripada 0,05, maka hal ini menunjukkan bahwa variabel Motivator (X1) dan Hygiene (X2) berpengaruh bersama-sama secara signifikan terhadap Komitmen Organisasional guru MI Islamiyah Madiun

Motivator (X1) terdiri dari 5 dimensi yaitu pencapaian (prestasi), pengakuan dan penghargaan, tanggung jawab, peluang untuk tumbuh, dan pekerjaan itu sendiri. Masing-masing dimensi diukur dengan 3 pertanyaan. Pada pengujian hipotesis atas variabel bebas terhadap variabel terikat secara parsial melalui uji ${ }^{\prime}$, diketahui bahwa nilai $t$ hitung variabel bebas Motivator (X1) lebih besar daripada 
† tabel. Hal ini berarti variabel Motivator secara parsial brpengaruh secara signifikan terhadap Komitmen Organisasional guru MI Islamiyah Madiun. Pernyataan ini sesuai dengan

Hygiene (X2) terdiri dari 5 dimensi yaitu gaji, kondisi kerja, kebijakan organisasi, hubungan dengan rekan kerja, dan kualitas supervisi. Masing-masing dimensi diukur dengan 3 pertanyaan. Pada pengujian hipotesis atas variabel bebas terhadap variabel terikat secara parsial melalui uji $\dagger$, diketahui bahwa nilai $\dagger^{\prime}$ hitung variabel bebas Hygiene (X2) lebih besar daripada $\dagger$ tabel. Hal ini berarti variabel Hygiene secara parsial brpengaruh secara signifikan terhadap Komitmen Organisasional guru MI Islamiyah Madiun.

Variabel Komitmen Organisasional guru (Y) merupakan variabel terikat dalam penelitian ini dimana variabel komitmen organissional merupakan variabel yang dipengaruhi oleh variabel Motivator (X1) dan Hygiene (X2)

Dari kedua faktor Herzberg yaitu motivator dan Hygiene, faktor motivator memiliki pengaruh yang dominan terhadap komitmen organisasional. Hal tersebut tentunya merupakan suatu hal yang baik karena guru di MI Islamiyah sudah meletakkan kebutuhan tingkat tinggi seperti kebutuhan untuk berprestasi dan berkembang, dalam bekerja di MI Islamiyah Madiun. Faktor Motivator tersebut telah mendorong guru untuk bekerja dengan sungguh-sungguh dan bersedia untuk mempertahankan keanggotannnya di Ml Islamiyah Madiun.

Dari hal di atas pimpinan $\mathrm{Ml}$ Islamiyah bisa mendukung guru MI Islamiyah Madiun untuk berprestasi baik di tingkat internal mapun eksternal sekolah. Selain itu, pimpinan harus terus memberikan penghargaan, baik berupa materi maupun non materi karena guruguru MI Islamiyah Madiun sangat mencintai pekerjaannya.

Adanya motivasi dari organisasi dan dari dalam diri guru itu sendiri, guru akan memiliki komitmen terhadap organisasinya. Hal ini sesuai dengan pendapat Trisnaningsih (2003) bahwa motivasi untuk mencapai target yang sudah ditetapkan oleh perusahaan dapat mempengaruhi komitmen pada organisasi sebagai upaya mewujudkan tujuan bersama. Hasil penelitian ini juga mendukung penelitian yang dilakukan oleh Burton, James P., Thomas W Lee, Brooks C Holtom (2002) yang menjelaskan bahwa karyawan yang memiliki motivasi tingi

\section{SIMPULAN DAN SARAN}

\section{A. Simpulan}

Berdasarkan hasil analisis data dan pengujian hipotesis pada bab sebelumnya maka dapat dikemukakan simpulan dari penelitian sebagai berikut :

1. Hasil penelitian menunjukkan ada pengaruh bersama-sama variabel motivasi yang terdiri dari Motivator (X1) dan Hygiene (X2) secara bersama-sama terhadap Komitmen Organisasional dengan nilai $F$ hitung 
sebesar 105,532 dengan tingkat signifikansi 0,000 . Dari hasil tersebut maka Ho ditolak dan $\mathrm{Ha}$ diterima. Besarnya koefisien korelasi berganda $(R)=0,876$ menunjukkan hubungan bersama-sama yang sangat kuat antara Motivator (X1) dan Hygiene (X2) terhadap Komitmen Organisasional. Sedangkan nilai koefisien determinasi berganda $\left(R^{2}\right)$ $=0,767$ berarti secara bersama-sama $76,7 \%$ perubahan variabel terikat $(Y)$ yaitu Komitmen Organisasional disebabkan oleh variabel motivasi. Sedangkan sisanya yaitu $23,3 \%$ disebabkan oleh variabel lain yang tidak masuk dalam model.

2. Hasil penelitian juga menunjukkan ada pengaruh parsial variabel Motivator (X1) dan Hygiene (X2) yang seluruhnya memiliki tingkat signifikansi lebih kecil dari 0,05. Dari hasil tersebut maka hipotesis penelitian kedua diterima kebenarannya. Berdasarkan nilai beta diketahui bahwa variabel motivator mempunyai pengaruh dominan terhadap Komitmen Organisasional.

\section{B. Saran}

Setelah melalui proses penelitian yang dilakukan, maka dapat diberikan saran sebagai masukan bagi peneliti maupun bagi $\mathrm{Ml}$ Islamiyah Madiun sebagai berikut:

1. Disarankan pada pihak MI Islamiyah untuk mempertahankan dan lebih meningkatkan kinerja karyawannya, karena terbukti dari penelitian ini terbukti bahwa faktor motivasi : Motivator dan Hygiene mempunyai pengaruh yang signifikan terhadap Komitmen Organisasional. Selanjutnya, diharapkan faktor motivasi tersebut mendapat perhatian yang lebih dari pimpinan MI Islamiyah sehingga komitmen guru dapat ditingkatkan.

2. Pihak Ml Islamiyah seharusnya memperhatikan faktor Motivator untuk meningkatkan Komitmen Organisasional. Karena dalam penelitian ini faktor Motivator (X1) merupakan faktor motivasi yang memiliki pengaruh paling dominan terhadap Komitmen Organisasional.

3. Penelitian berikutnya dapat dilakukan dengan melakukan penelitian tentang motivasi kerja di tempat kerja dengan menambahkan variabel kepuasan kerja atau kompensasi dalam perspektif Islam.

\section{DAFTAR PUSTAKA}

Al Qur'an Dan Terjemahannya. 2010. Departemen Agama Republik Indonesia.

Amin, Ayoeb. 2010. Pengaruh Komitmen Kerja Islami Terhadap Motivasi Kerja dan Status Pendapatan serta Kesejahteraan Kelvarga Muslim di Kabupaten Pekalongan, Provinsi Jawa Tengah. Disertasi tidak diterbitkan. Surabaya Fakultas 
Ekonomi dan Bisnis Universitas Airlangga.

Anshori, Muslich dan Iswati . 2009. Buku Ajar Metodologi Penelitian Kuantitatif. Surabaya : Pusat Penerbitan dan Percetakan Unair. Burton, James P, dkk. 2002. The Influence of Motivation to Attend, Ability to Attend, and Organizational Commitment on Different Types of Absence Behaviors. Journal of Managerial Issues, Summer, p. 181197

Daft, Richard L. 2003. Manajemen. (Terjemahan Emil Salim dan Iman Karmawan). Edisi kelima. Jakarta : Erlangga.

Djamarah, Syaiful Bahri. 1994. Prestasi Belajar Dan Kompensasi Guru. Cetakan Pertama. Surabaya : Usaha Nasional.

Ghozali, Imam. 2001. Analisis Multivariat dengan Program SPSS. Semarang : Universitas Diponegoro.

Hamalik, Oemar. 1993. Psikologi Manajemen. Bandung : Trigenda Karya.

Hasibuan, Malayu, S.P. 2001. Manajemen Sumberdaya Manusia. Edisi Revisi. Jakarta : PT. Bumi Aksara.

Kamaluddin, Rustian. 1999. Pengantar Ekonomi Pembangunan. Jakarta : LPFE UI.

Kamus Besar Bahasa Indonesia. 1998. Departemen Pendidikan Dan Kebudayaan. Jakarta : Balai Pustaka.
Khaliq, Ahmad, dkk. 2011. Isuves in Islamic Management : Theories and Practices. Selangor : IIUM Press

Kuncoro, Mudrajad. 2009. Metode Riset untuk Bisnis dan Ekonomi. Jakarta : Erlangga.

Lieke. 2010. Pengaruh Motivasi dan Kompensasi Terhadap Komitmen Organisasional di Organisasi Pendidikan Islam. Jurnal Managemen.

Luth, Thohir. 2001. Antara Perut Dan Etos Kerja Dalam Perspektif Islam. Jakarta : Gema Insani.

Muafi. 2003. "Pengaruh Motivasi Spiritual Karyawan Terhadap Kinerja Religius". Yogyakarta. Fakultas Ekonomi Universitas Pembangunan Nasional "Veteran" Yogyakarta.

Rahim, Husni. 2001. Arah Baru Pendidikan Islam Di Indonesia. Jakarta : Logos Wacana IImu.

Rivai, Veithzal. 2009. Islamic Human Capital. Dari Teori Ke Praktik Manajemen Sumber Daya Islami. Jakarta : Rajawali Pers.

Robbins, Stephen $P$ and Timothy Judge. 2008. Perilaku Organisasi. Penerjemah Diana Angelica dkk.. Jakarta : Salemba Empat.

Shihab, M.Quraish. 2002. Tafsir Al Misbah : Pesan, Kesan Dan Keserasian Al Qur'an. Jakarta : Lentera Hati.

Soemanto, Wetsy. 1998. Psikologi Pendidikan. Jakarta: Rineka Cipta. Sopiah. 2008. Perilaku Organisasional. Yogyakarta : Penerbit Andi. 
Sugiyono. 2011. Statistika untuk Penelitian. Bandung : Alfabeta.

Sutrisno, Edy. 2009. Manajemen Sumber daya Manusia. Jakarta : Kencana.

Syafitri, Maylina. 2012. Pengaruh Motivasi Spiritual Islam Terhadap Prestasi Belajar Mahasiswa Ekonomi Islam FEB Universitas Airlangga Surabaya. Skripsi Tidak Diterbitkan. Surabaya Fakultas Ekonomi Dan Bisnis Universitas Airlangga

Tasmara, Toto. 2002. Membudayakan Etos Kerja Islami. Jakarta: Gema Insani. 2013. 7 Menit Mengenal Islam. Jakarta: Gema Insani.

Trisnaningsih, Sri. 2003. Pengaruh Kepuasan Terhapdap Komitmen Auditor : Motivasi Sebagai Varoabel Intervening Studi Empiris Pada Kantor Akuntan Public di Jawa Timur. Jurnal Riset Akuntansi Indonesia, vol. 6 no. 2 Mei 2003. Yogyakarta : Universitas Gajah Mada.

Undang-Undang Republik Indonesia Nomor 20 tahun 2003 Tentang Sistem Pendidikan Nasional.

www. Journal.uii.ac.id. Data Statistik Madrasah. Diakses tanggal 27 Mei 2013.

Yamin, Sofyan dan Heri Kurniawan. 2009. SPSS Complete: Teknik Analisis Statistik Terlengkap dengan Software SPSS. Jakarta : Salemba Infotek.

Zamroni. 2000. Paradigma Pendidikan Masa Depan. Yogyakarta : Bigraf Publishing. 